\title{
Characterization of Phase Transformations and Microstructural Changes in an API 5CT L80 Steel Grade During Ni Alloy Laser Cladding
}

\author{
Geraldo Lúcio de Faria ${ }^{a}{ }^{\star}$, Jorge Magalhães Avila de Paula ${ }^{a}$, Milton Sérgio Fernandes de Lima \\ ${ }^{a}$ Universidade Federal de Ouro Preto, Campus Universitário do Morro do Cruzeiro, 35400-000, Ouro \\ Preto, MG, Brasil \\ 'Instituto Tecnológico de Aeronáutica, Praça Marechal Eduardo Gomes, 50, Vila das Acácias, 12228- \\ 900, São José dos Campos, SP, Brasil
}

Received: April 21, 2018; Revised: May 22, 2018; Accepted: July 05, 2018

\begin{abstract}
The superficial coatings in micro-alloyed steel pipes has been a pointed way to decrease the corrosion problems in oil and gas industry. However, little emphasis has been given to the substrate. The effects of the deposition method on the steel microstructure and properties are still not well described. In this context, this work studied the effect of Ni superalloys clads on the phase transformations, microstructure and hardness of the heat-affected zone (HAZ) of an API steel. The underestimate of the HAZ might be dangerous, since, despite the coating good corrosion performance, the substrate HAZ may present a weak region, which may lead to an in-service coating tearing. In this work, Inconel 625 and Hastelloy C276 superalloys were clad on the steel surface by a laser deposition. Dilatometry, optical and scanning electron microscopy, and computational simulation were applied. The studied steel was originally constituted by tempered martensite. The austentizing temperature had a strong influence on the austenite grain size and on the steel CCT diagram. Due to that, the laser superalloy deposits promoted a complex HAZ, where grain growth occurred. A post-cladding heat treatment was proposed to homogenize the steel microstructure and to decrease the hardness gradient at the superalloy-steel interface.
\end{abstract}

Keywords: Laser cladding, API 5CT L80, heat-affected zone, post-cladding heat treatment.

\section{Introduction}

The use of steel pipes in the oil \& gas industry is growing around the world ${ }^{1}$. However, the need to replace components due to the occurrence of failures related to its high susceptibility to corrosion is frequent. This occurs because most of the fluids processed in a petrochemical industry have corrosive agents, which, in contact with the steel surface, are harmful to the component superficial integrity and can lead it to catastrophic failure, mainly by fatigue-corrosion ${ }^{2,3}$.

Highlighting the importance of this problem, it is feasible to study technological alternatives to avoid or delay this type of corrosion on the pipe inner walls. An option that has been studied is the application of special coatings with high corrosion resistance on the internal pipe walls. As an example, Ni superalloy coatings have been studied by several researchers with the focus on pipe corrosion behavior. In the literature, several deposition methods have been evaluated, such as thermal spray, welding processes, and laser deposition. The laser deposition process has been studied lately by focusing on the mechanical and chemical performance of the coat and its interface to steel. However, the understanding of the cladding effect on the base material region next to the clad, called heat affected zones (HAZ), is missed in the state of the art. ${ }^{4-16}$.

*e-mail: geraldolfaria@yahoo.com.b
All thermal-induced deposition processes may generate a significant heat-affected zone (HAZ) on the substrate during deposition. The technical literature presents that four different defects may occur in the HAZ of overlay clad steels: hardening, excessive grain growth, hydrogen cracking and liquation. Due to the occurrence of some of these effects, a gradient of mechanical properties is expected. Therefore, in case of a large difference in mechanical behavior near the clad-substrate interface, despite the coating good corrosion performance, the component may be sensitive to fatigue cracking, which may lead to the tearing of the coated layer during the pipe operation ${ }^{17-20}$.

In this context, this work investigated the effect of the laser deposition of Ni superalloys (Inconel 625 and Hastelloy C276) on the API 5CT L80 steel HAZ. Aspects such as phase transformations, microstructure and hardness were evaluated. A post-cladding heat treatment was also studied aiming to decrease the microstructural and hardness gradient near to the superalloy-steel interface.

\section{Materials and Methods}

Initially, an as-received sample from the wall of an API 5CT L80 steel pipe (seamless pipe - $13.84 \mathrm{~mm}$ wall thickness) was sectioned and chemical and microstructurally characterized. The initial state was hot rolled, quenched and 
tempered at $650^{\circ} \mathrm{C}$ for $1 \mathrm{~h}$. Then, the steel substrates were submitted to Inconel 625 and Hastelloy C276 alloy laser clads.

The chemical analysis were performed by optical emission spectrometry and the microstructural characterization by optical and scanning electron microscopy techniques. The samples were ground, polished and etched with Nital $4 \%$. The Vickers microhardness tests were also performed using a load of $10 \mathrm{gf}$.

In order to experimentally determine the austenitizing critical temperatures Ac1 and Ac3, as well as the steel Continuous Cooling Transformation (CCT) diagram, dilatometric experiments were carried out. Twelve cylindrical specimens were machined $($ diameter $=3.0 \mathrm{~mm}$, height $=10.0 \mathrm{~mm})$ and heated from room temperature to $950^{\circ} \mathrm{C}$ with a constant heating rate of $5^{\circ} \mathrm{C} / \mathrm{s}$. The dilatometric curves were obtained and the Ac1 and Ac3 temperatures were measured using the minimal linear deviation method ${ }^{21,22}$. From the obtained results, the Ac1 and Ac3 average values were calculated.

Aiming to experimentally determine the CCT diagram of the studied steel, 24 cylindrical specimens were machined, with the same dimensions previously described, and two different austenitizing temperatures were evaluated $\left(950^{\circ} \mathrm{C}\right.$ and $1150^{\circ} \mathrm{C}$ ). In both austenitizing conditions, samples were $5^{\circ} \mathrm{C} / \mathrm{s}$ heated until the desired temperature, with an isothermal stage of 30 seconds. The fully austenitized samples were then cooled down to room temperature, under continuous Helium gas flow and different cooling rates: $200^{\circ} \mathrm{C} / \mathrm{s}$; $100^{\circ} \mathrm{C} / \mathrm{s} ; 75^{\circ} \mathrm{C} / \mathrm{s} ; 50^{\circ} \mathrm{C} / \mathrm{s} ; 25^{\circ} \mathrm{C} / \mathrm{s} ; 15^{\circ} \mathrm{C} / \mathrm{s} ; 10^{\circ} \mathrm{C} / \mathrm{s} ; 7.5^{\circ} \mathrm{C} / \mathrm{s}$; $5^{\circ} \mathrm{C} / \mathrm{s} ; 2.5^{\circ} \mathrm{C} / \mathrm{s} ; 1^{\circ} \mathrm{C} / \mathrm{s}$ and $0.5^{\circ} \mathrm{C} / \mathrm{s}$. For both austenitizing conditions, the samples which were submitted to cooling rates of $100^{\circ} \mathrm{C} / \mathrm{s}, 10^{\circ} \mathrm{C} / \mathrm{s}, 5^{\circ} \mathrm{C} / \mathrm{s}$ and $0.5^{\circ} \mathrm{C} / \mathrm{s}$ were characterized using optical and scanning electron microscopy and Vickers microhardness tests.

The Inconel 625 and Hastelloy C276 alloy powders were laser deposited on the studied steel (substrate). The parameters used in the laser deposition process were: argon protection gas; speed of $240 \mathrm{~mm} / \mathrm{min}$.; laser power of $10 \mathrm{~kW}$ with 100 $\%$ power supply; the focal length of the used lens was 136 $\mathrm{mm}$. The used laser was a continuous wave $\mathrm{CO}_{2}$ type with beam mode approximately top-hat. The material was cladded with a single layer, with a lateral superposition of $50 \%$. In order to better understand the thermal events to which the substrate was submitted, a computational simulation was carried out, based on the Rosenthal model (Equation 1) ${ }^{23}$.

$$
\Delta T(x, y, z)=\frac{\beta \cdot P}{2 \pi K r} \exp \left\{-\frac{V}{2 \alpha}(x+r)\right\}
$$

Where $\Delta \mathrm{T}$ is the temperature raise in the substrate $(\mathrm{K}), \mathrm{P}$ is the laser power (W), $\beta$ is the absorptivity (dimensionless unit), $\mathrm{K}$ is the substrate thermal conductivity ( $\mathrm{W} / \mathrm{mK}), \mathrm{V}$ is the laser displacement rate $(\mathrm{m} / \mathrm{s}), \alpha$ is the substrate thermal diffusivity $\left(\mathrm{m}^{2} / \mathrm{s}\right)$. Equation 1 represents the temperature distribution in a Cartesian referential for a point source that focuses on the point $(\mathrm{x}=0, \mathrm{y}=0, \mathrm{z}=0)$ on the material surface. Therefore, the radius $r$ is equal to $\left(x^{2}+y^{2}+z^{2}\right)^{(1 / 2)}$.

Since $\mathrm{K}$ and $\alpha$ are material constants and $\mathrm{P}$ and $\mathrm{V}$ are laser parameters, the unknown variable $\beta$ is the absorptivity. The value of $\beta$ varies freely between 0 and 1 for a fully reflecting body of laser radiation (white body) or fully radiation absorbing (black body), respectively. In most published works, the value of ( is adjusted aiming to fit the calculated temperature field to the experimentally observed data ${ }^{23,24}$.

The samples containing the laser deposited alloys (Hastelloy and Inconel 625) were metallographically prepared and etched using an ether solution ( $50 \mathrm{ml}$ of ether, $80 \mathrm{ml}$ of distilled water, $0.5 \mathrm{ml}$ of $\mathrm{HCl}, 3$ grams of picric acid and 25 $\mathrm{ml}$ of neutral detergent, shaking 2 hours before using it) for 4 minutes and a half, and then with Nital $2 \%$ for 20 seconds. The sample evaluations were performed by optical (OM) focusing on steel microstructural changes.

The samples were subjected to Vickers microhardness tests with $10 \mathrm{gf}$ loading. The microhardness profiles were measured from the clad to the steel substrate. At superalloy layers, the distance between measured points was continuously decreased from $0.5 \mathrm{~mm}$ to $0.1 \mathrm{~mm}$. At the steel substrate, this distance was held constant until $1.5 \mathrm{~mm}$, and then, continually increased to $0.5 \mathrm{~mm}$, as presented in Figure 1.

After the characterization and the understanding about the effect of the laser cladding procedure on steel microstructure and hardness profile at superalloy-steel interface, a postcladding heat treatment was proposed seeking to obtain a homogeneous distribution at this critical area.

\section{Results and Discussion}

\subsection{Base Metal}

The as received steel characterization was performed. Table 1 presents the steel chemical composition and Figure 2 presents OM and SEM micrographs. The studied steel meets the chemical composition requirements for an API 5CT L80 grade manufacturing. Its microstructure is mainly constituted by tempered martensite. This result is according to technical literature and industrial data, because API 5CT L80 steels are usually quenched and tempered steels ${ }^{25}$.

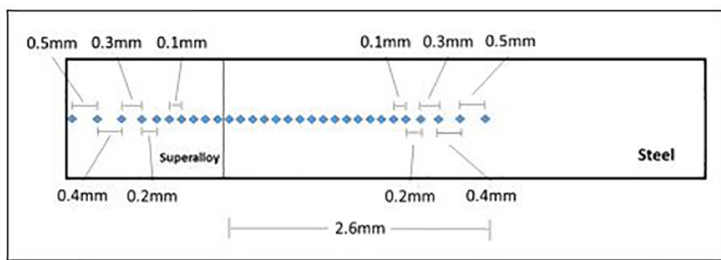

Figure 1. Schematic figure exemplifying the microhardness measurement throughout the sample. 
Table 1. Steel chemical composition (wt.\%).

\begin{tabular}{lcccccc}
\hline $\mathrm{C}$ & $\mathrm{Mn}$ & $\mathrm{Ni}$ & $\mathrm{Cu}$ & $\mathrm{P}$ & $\mathrm{S}$ & $\mathrm{Si}$ \\
\hline 0.25 & 1.2 & 0.04 & 0.07 & 0.02 & 0.003 & 0.2 \\
\hline
\end{tabular}
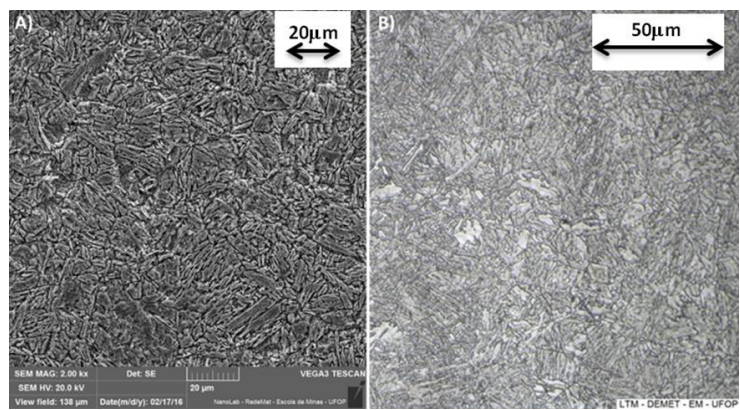

Figure 2. Microstructure of the studied steel, as produced. Nital 4\%: A) SEM-SE 2000x; B) OM 500x.

\subsection{Superalloys-cladded steel}

The laser deposition of nickel superalloys (Inconel 625 and Hastelloy C276) was carried out on the substrate according to the previously reported procedure. Figure 3 presents the photos of the samples after cladding. The samples were then evaluated by Vickers microhardness tests and OM analyses. Figures 4 and 5 show the obtained results.
It was noticed in Figure 4 that the hardness values along the two nickel superalloy layers (Inconel 625 and Hastelloy C276) are practically constants, with average values around $180 \mathrm{HV}$ for both. The steel hardness varied sharply close to the region next to the interface, reaching its maximum value $(350 \mathrm{HV})$ at approximately $0.7 \mathrm{~mm}$ from the superalloy-steel interface, and stabilizing in the steel substrate at approximately $1.7 \mathrm{~mm}$ from the interface. This hardness profile was observed in both samples.

Aiming to understand the hardness profile at the superalloy-steel interface, OM analysis were performed on both coated samples and the obtained result was the same. It was possible to verify the presence of coarse martensite, with lath morphology, next to the interface (Figure 5A). Moving away from the interface, the microstructure refinement was noticeable, and acicular martensite was predominant (Figure 5B). Figure 5B also represents a transition area between a fine martensitic microstructure (left side) and a mixed zone constituted by martensite and ferrite (white areas in Figure 5B on the right side). In Figure 5C, it was possible to observe the ferrite predominance. This area was associated to a specific sample region where the temperature did not reach the austenitizing temperature and the original martensitic structure were strongly tempered. It is important to highlight that the same behavior was observed in both coated samples.
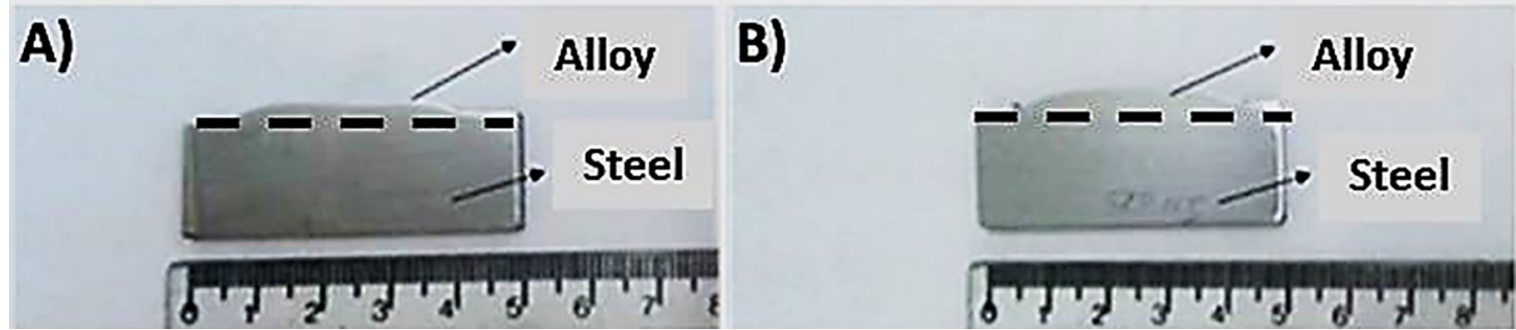

Figure 3. Photos of the steel samples coated with nickel superalloys: A) Hastelloy C276, B) Inconel 625.

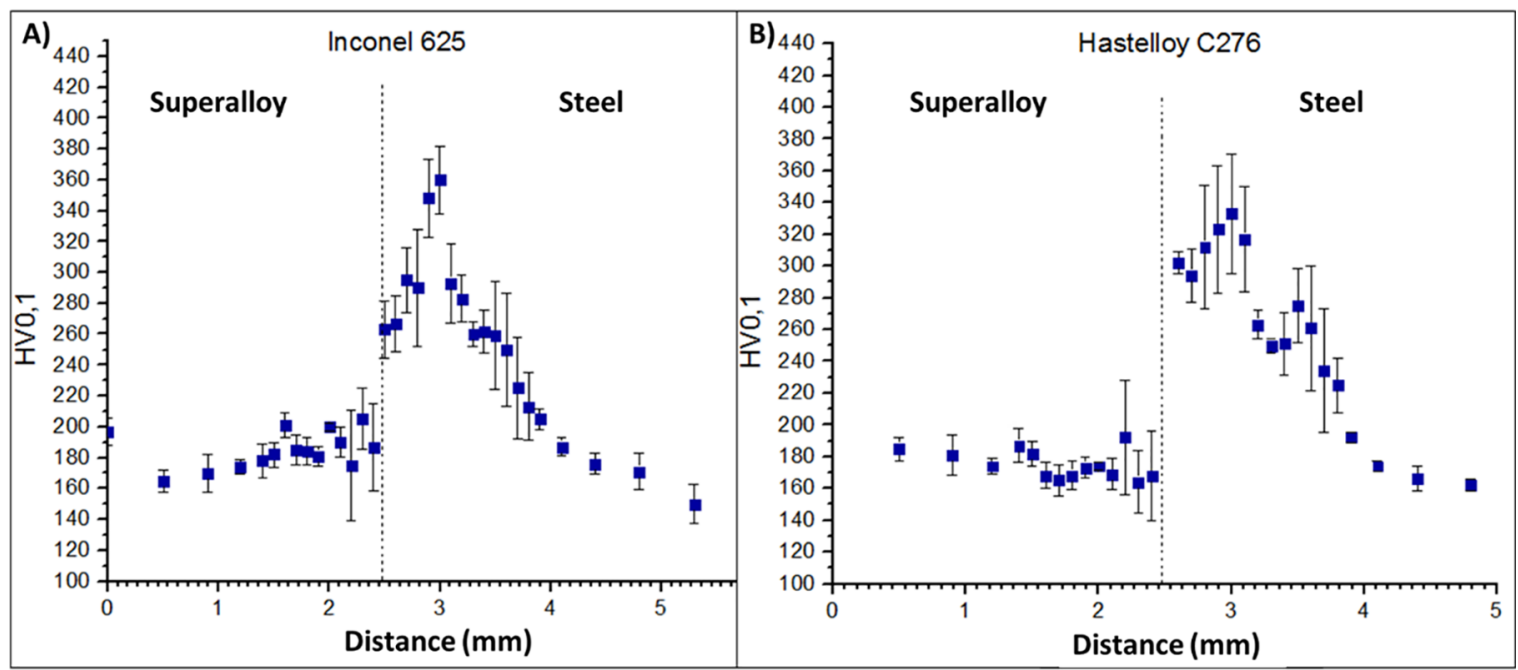

Figure 4. Microhardness profiles of nickel superalloys-steel interfaces: A) Inconel 625, B) Hastelloy C276. 


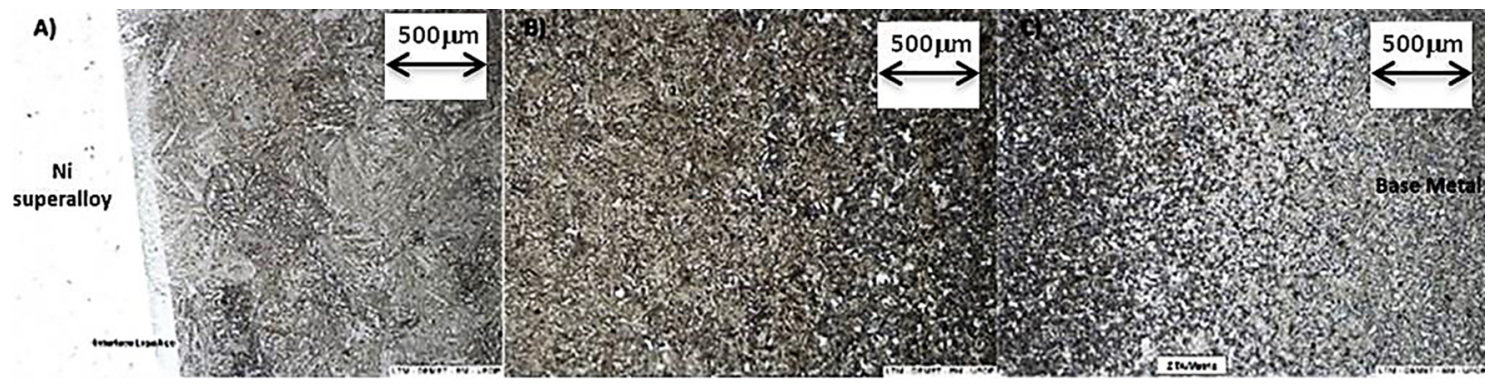

Figure 5. Microstructures of the steel substrate: A) at the superalloy-steel interface, presenting coarse martensite in this region; B) right away from the alloy-steel interface, presenting a more refined martensite in this region; C) transition zone from martensite-ferrite to the tempered substrate area. Nital $2 \%$. OM 200x.

\subsection{Dilatometry}

Aiming understand the effect of heating cycles imposed to the steel during the cladding procedures, dilatometric studies were carried out. The steel samples were submitted to dilatometric tests to determine Ac1 and Ac3 temperatures and to obtain the CCT diagrams for two austenitizing temperatures $\left(950^{\circ} \mathrm{C}\right.$ and $\left.1150^{\circ} \mathrm{C}\right)$. These temperatures were selected to simulate two different areas of steel sample that were heated to different temperatures during the cladding procedure.

The average temperatures Ac1 and Ac3 measured for the studied steel were $739 \pm 11^{\circ} \mathrm{C}$ and $852 \pm 5^{\circ} \mathrm{C}$, respectively. Figures 6 and 7 presents the steel CCT diagrams for both austenitizing temperatures. It was observed that the transformation lines in the sample heated at the highest temperature are slightly shifted to the right and down (critical cooling rate: $15^{\circ} \mathrm{C} / \mathrm{s}$ ) in comparison to the lowest temperature (critical cooling rate: $20^{\circ} \mathrm{C} / \mathrm{s}$ ). This result is in agreement with the literature. According to previous studies, higher the austenitization temperature and higher the austenitic grain size, lower the nucleation of the diffusional constituents, favoring martensite even with lower cooling rates $\mathrm{s}^{26-28}$.

Four samples submitted to the cooling rates, $0.5^{\circ} \mathrm{C} / \mathrm{s}$, $5^{\circ} \mathrm{C} / \mathrm{s}, 10^{\circ} \mathrm{C} / \mathrm{s}$, and $100^{\circ} \mathrm{C} / \mathrm{s}$, were characterized in order to verify the obtained microstructures. Figures 8 and 9 present the SEM obtained micrographs.

The samples austenitized at $950^{\circ} \mathrm{C}$ and at $1150^{\circ} \mathrm{C}$, and submitted to $0.5^{\circ} \mathrm{C} / \mathrm{s}$ cooling rate, were mainly constituted by ferrite and pearlite (Figures $8 \mathrm{~A}$ and $9 \mathrm{~A}$ ). However, an important difference was observed in the ferrite fraction and morphology. For the lowest austenitization temperature, a higher ferrite fraction was observed, with predominant equiaxial morphology, whereas for the highest austenitization temperature, a preferential acicular morphology was verified. This happens because at $1150^{\circ} \mathrm{C}$, the austenite grains grew, hindering the nucleation and growth of the equiaxial ferrite.

For $5^{\circ} \mathrm{C} / \mathrm{s}$ cooling rate, when the austenitizing temperature was $950^{\circ} \mathrm{C}$, allotriomorphic ferrite and cementite precipitation were verified (Figure $8 \mathrm{~B}$ ). For $1150^{\circ} \mathrm{C}$, the ferrite fraction was significantly lower, with predominance of acicular morphology. Bainite was the major constituent (Figure $9 \mathrm{~B}$ ).

For the cooling rate of $10^{\circ} \mathrm{C} / \mathrm{s}$, the formation of bainite and martensite was observed for the both austenitizing temperatures. The sample austenitized at $950^{\circ} \mathrm{C}$ (Figure $8 \mathrm{C}$ ) had still granular ferrite remnants. Finally, for $100^{\circ} \mathrm{C} / \mathrm{s}$ cooling rate, martensite formation was observed for both austenitizing conditions. However, for the austenitized sample at $950^{\circ} \mathrm{C}$
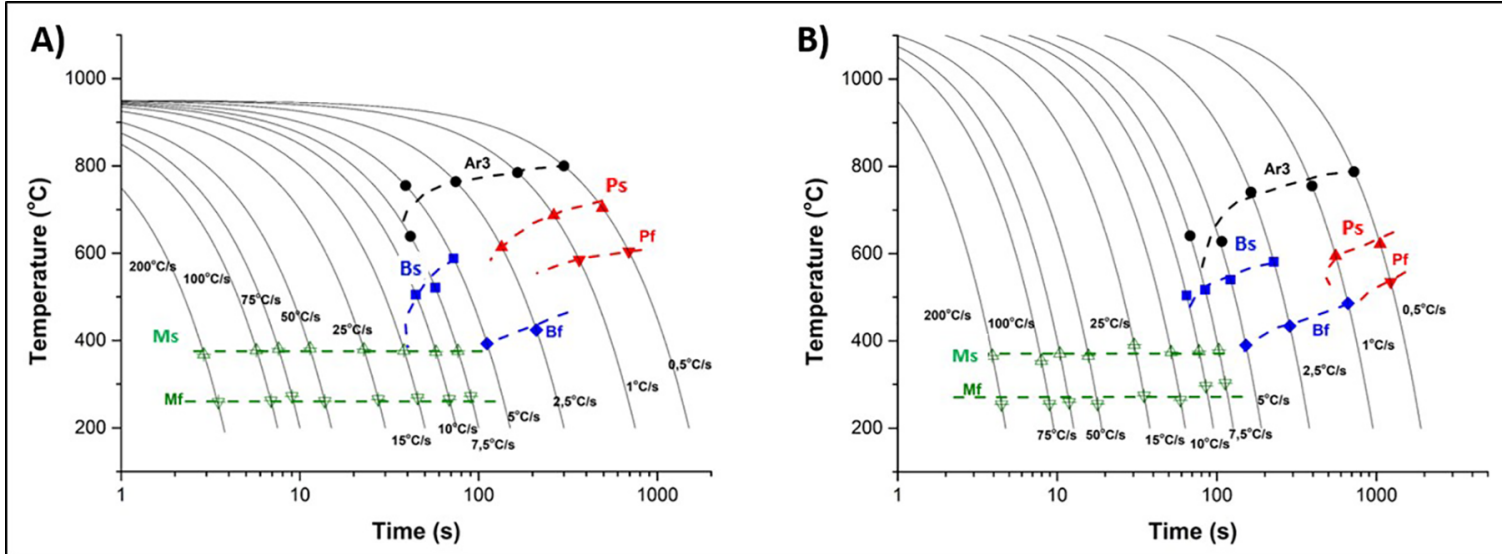

Figure 6. CCT diagrams of the studied steel A) austenitized at $\left.950^{\circ} \mathrm{C} ; \mathrm{B}\right)$ austenitized at $1150^{\circ} \mathrm{C}$. (Ar3-start of austenite to primary ferrite decomposition, Ps - start of pearlitic transformation, Pf - final of pearlitic transformation, Bs- start of bainitic transformation, Bf - final of bainitic transformation, Ms - start of martensitic transformation; Mf - final of martensitic transformation). 
(Figure 8D), a more refined martensite was observed in relation to the other one austenitized at $1150^{\circ} \mathrm{C}$ (Figure 9D).

The Vickers microhardness tests were performed on samples submitted to dilatometric tests, Figure 10. It can be stated that for the same cooling rate, the hardness changed as a function of the austenitizing temperature. The lower the austenitizing temperature and the lower the austenite grain size, the lower the thermodynamic potential for recovering of defects in the crystal structure. More defects imply more preferred sites for heterogeneous nucleation of diffusional constituents, such as ferrite, pearlite and bainite, accelerating phase transformations $\mathrm{s}^{29,30}$. At $10^{\circ} \mathrm{C} / \mathrm{s}$ cooling rate, and below, there is still equiaxial primary ferrite formation in samples

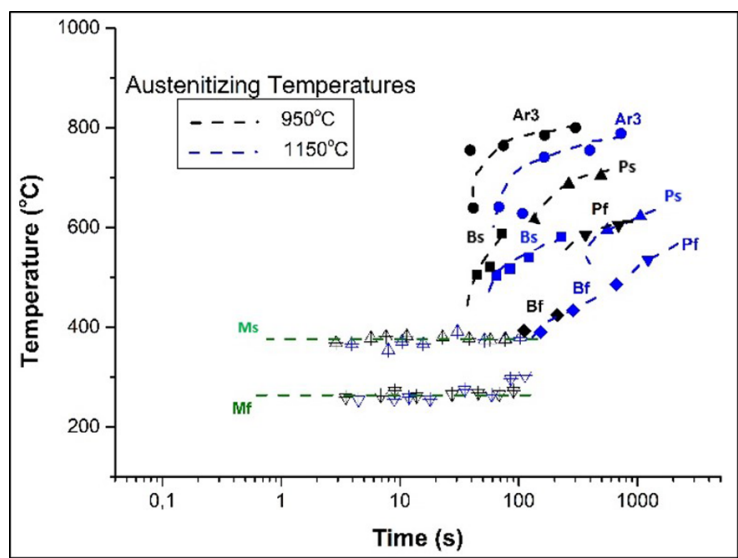

Figure 7. Comparison between CCT diagrams highlighting the effect of the austenitizing temperature. austenitized at $950^{\circ} \mathrm{C}$ (Figure $8 \mathrm{C}$ ), becoming the material softer than the sample heated at $1150^{\circ} \mathrm{C}$ (Figure $9 \mathrm{C}$ ).

An inverse result was observed for samples cooled at $100^{\circ} \mathrm{C} / \mathrm{s}$. The sample austenitized at $1150^{\circ} \mathrm{C}$ presented a slightly lower hardness value than the sample heated at $950^{\circ} \mathrm{C}$. This occurred because the austenitic grains became relatively larger at $1150^{\circ} \mathrm{C}$ than at $950^{\circ} \mathrm{C}$. A more refined (acicular) martensite was evidenced for smaller austenitic grains. Thus, a more refined martensitic structure will exhibit a relatively higher hardness when compared to a coarser martensitic structure ${ }^{26-28}$. These results confirm the hypothesis that the main cause of the hardness heterogeneity verified at the superalloy-steel interface is the association of the gradient of prior austenitic grain sizes and the different martensite morphologies.

\subsection{Computational simulation}

Seeking to better understand the phenomenon, a computational simulation of the laser cladding procedure was carried out. Figure 11A highlights the main results in terms of temperature ranges as a function of sample depth during cladding. The deposited alloy layer was considered as $2.2 \mathrm{~mm}$ according to measurements performed in SEM images, as exemplify the Figure 11B. The others simulation conditions were already presented in materials and methods.

Analyzing the simulation results, and considering the steel Ac1 and Ac3 temperatures determined by dilatometry, it was possible to build the Figure 12. This figure highlights the highest reached temperature during the cladding
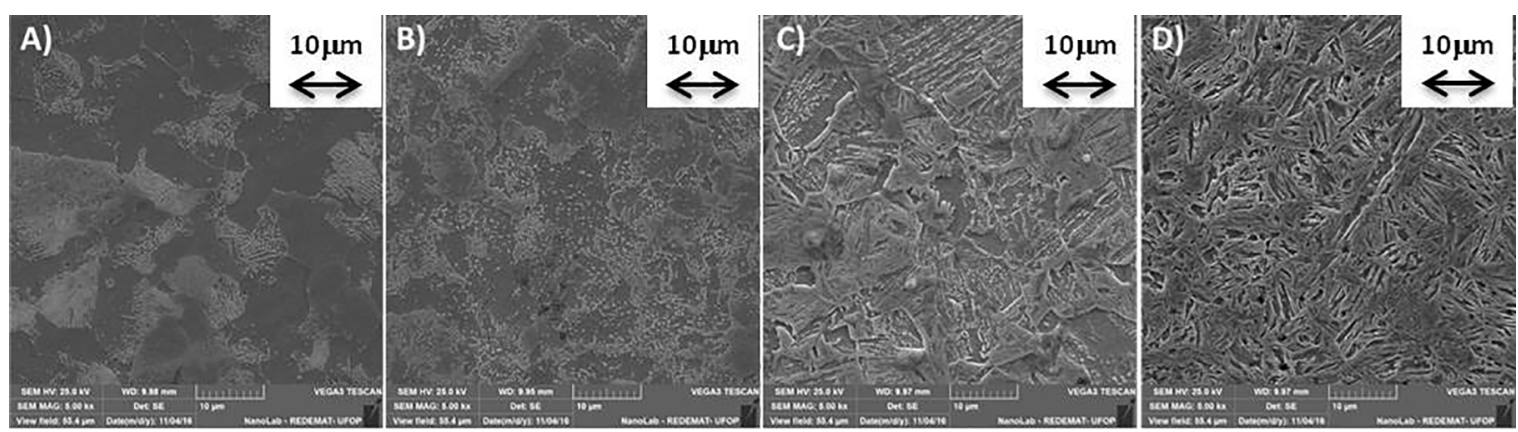

Figure 8. Microstructures of dilatometry samples austenitized at $950^{\circ} \mathrm{C}$. Cooling rates of A) $\left.\left.\left.0.5^{\circ} \mathrm{C} / \mathrm{s} ; \mathrm{B}\right) 5^{\circ} \mathrm{C} / \mathrm{s} ; \mathrm{C}\right) 10^{\circ} \mathrm{C} / \mathrm{s} ; \mathrm{D}\right) 100^{\circ} \mathrm{C} / \mathrm{s}$. Nital $4 \%$. SEM-SE 5000x.
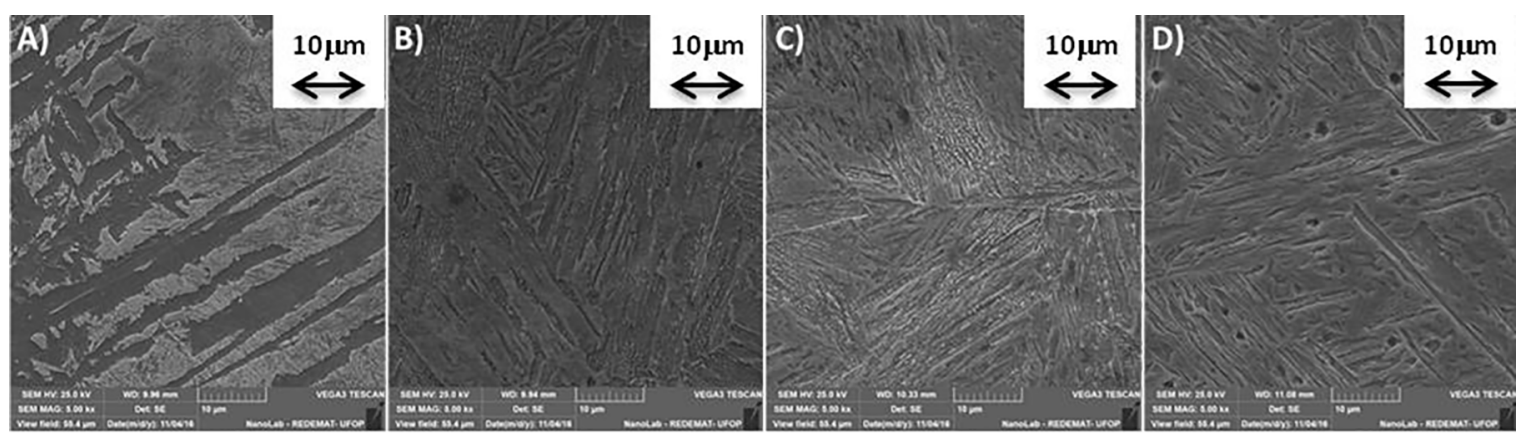

Figure 9. Microstructures of dilatometry samples austenitized at $1150^{\circ} \mathrm{C}$. Cooling rates of A) $\left.\left.\left.0.5^{\circ} \mathrm{C} / \mathrm{s} ; \mathrm{B}\right) 5^{\circ} \mathrm{C} / \mathrm{s} ; \mathrm{C}\right) 10^{\circ} \mathrm{C} / \mathrm{s} ; \mathrm{D}\right) 100^{\circ} \mathrm{C} / \mathrm{s}$. Nital $4 \%$. SEM-SE 5000x. 
procedure, for different points along the steel depth. As the steel Acl temperature is $739^{\circ} \mathrm{C}$, it can be affirmed that the HAZ where total or partial austenitization occurred during the superalloys deposition, is approximately $1.4 \mathrm{~mm}$ deep in relation to the interface.

It can be stated that, according to the simulation, the region where the complete austenitization occurred on steel has approximately $0.7 \mathrm{~mm}$ long from the superalloy-steel interface. This case depth corroborates the hardness profiles (Figure 4).

In order to better understand the relationship between the laser deposition process and the microstructural characteristics of the fully austenitized zone, the instantaneous and the average cooling rates for the $2.3 \mathrm{~mm}$ point from the surface

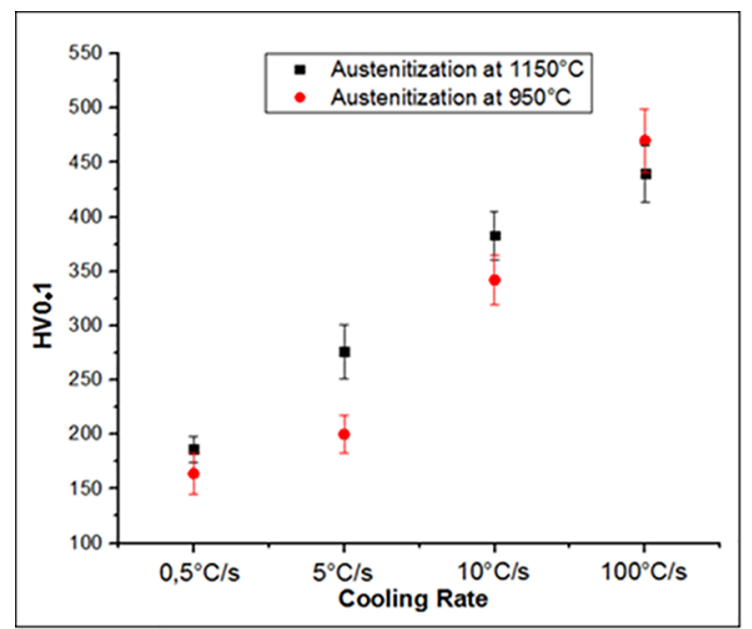

Figure 10. Average microhardness of the samples submitted to dilatometric tests.
(0.1 $\mathrm{mm}$ depth in steel from the superalloy-steel interface), and for the point $2.9 \mathrm{~mm}$ from the surface $(0.7 \mathrm{~mm}$ depth in steel from the superalloy-steel interface) were calculated (Figure 13). At these points, the highest temperatures were respectively $1100^{\circ} \mathrm{C}$ and $850^{\circ} \mathrm{C}$, close to the austenitizing temperatures evaluated by the dilatometry experiments.

The minimum average cooling rate obtained was $308^{\circ} \mathrm{C} / \mathrm{s}$ at $2.9 \mathrm{~mm}$ from the superalloy surface (Figure 13). Comparing this data with the steel CCT diagram (Figure 7), the presence of a martensitic structure is justified.

Evaluating dilatometry, microstructural analysis, and computational simulation results, it is possible to affirm that the highest hardness values occurred in the region of the steel where there is the beginning of full austenitization i.e.

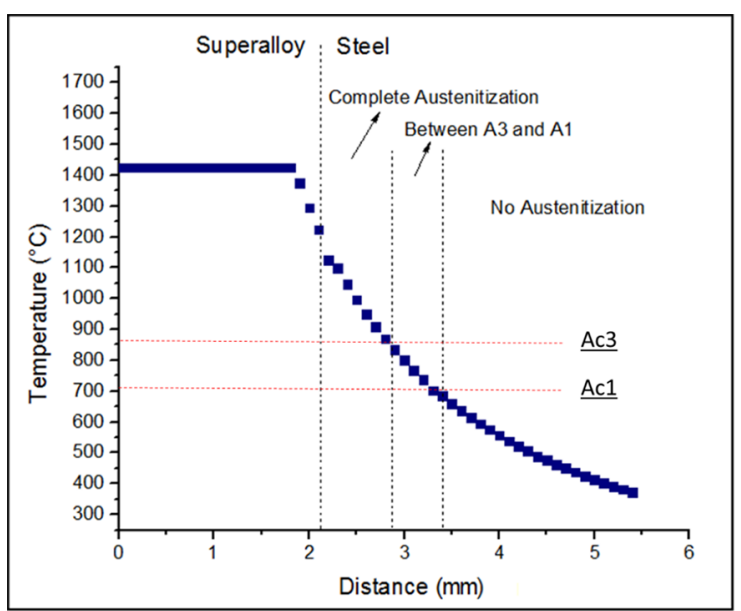

Figure 12. Temperature profile as a function of the distance from the free surface.

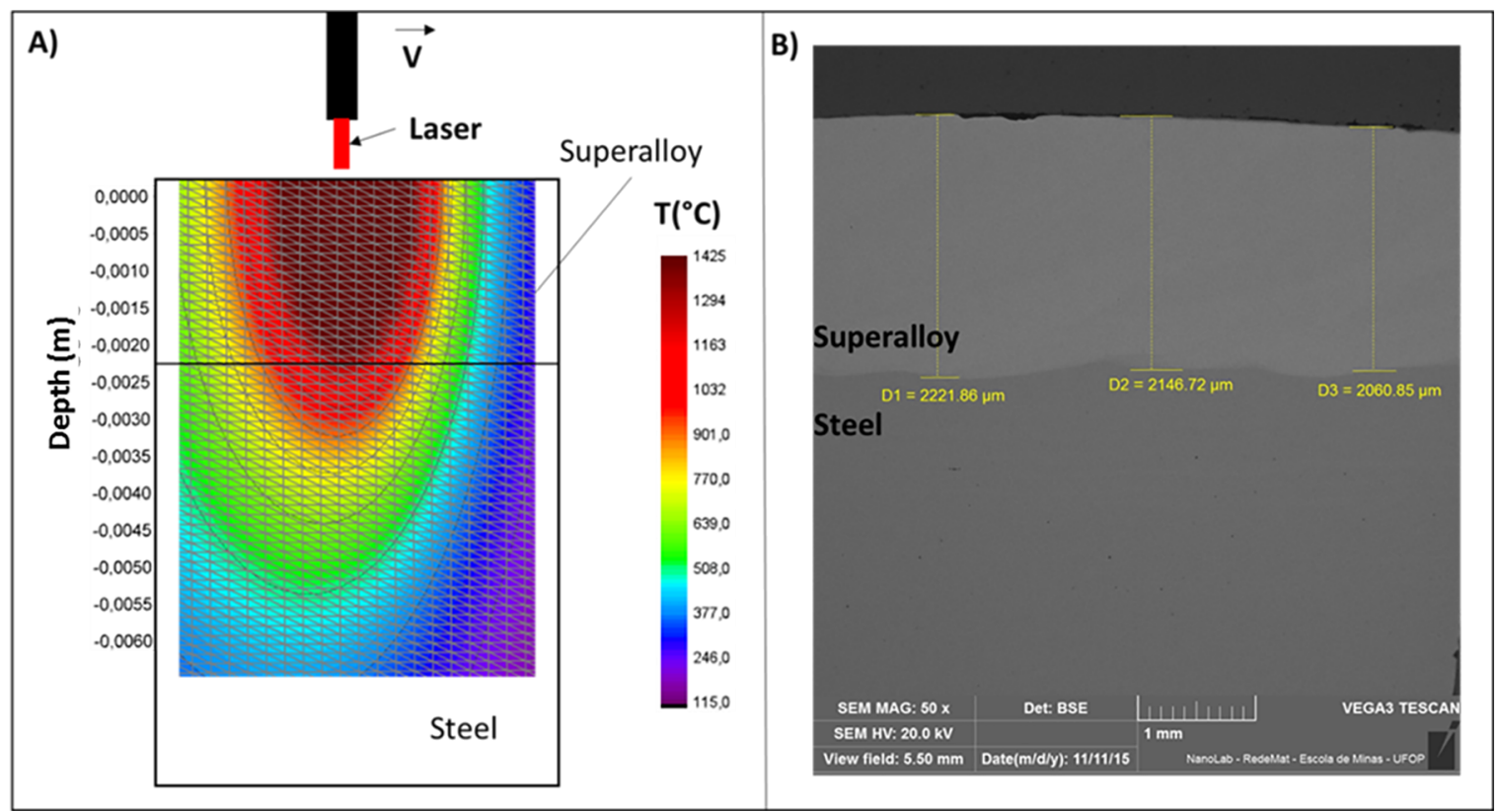

Figure 11. A) Instantaneous temperature profile obtained by computational simulation; B) SEM-BSE micrograph of the sample interface, illustrating the depth of deposited layers. 

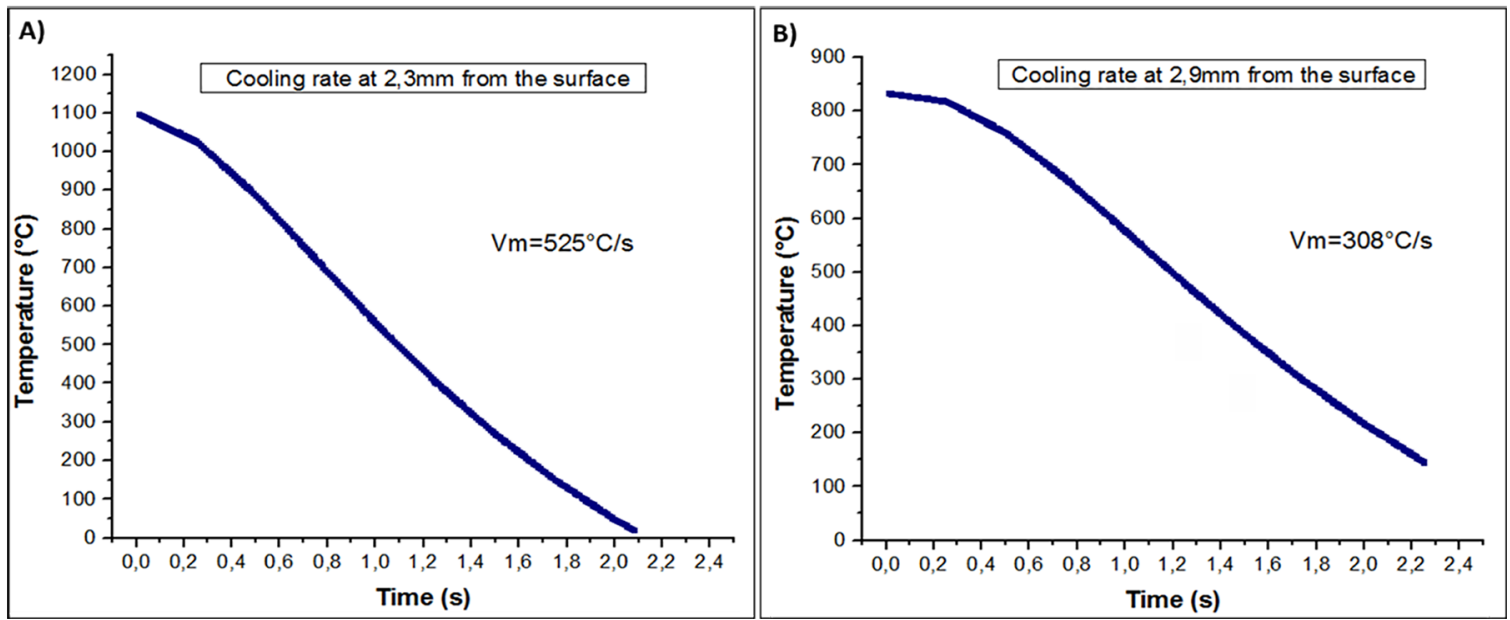

Figure 13. Cooling rate of A) point at $2.3 \mathrm{~mm}$ and B) from $2.9 \mathrm{~mm}$ from the superalloy surface calculated by computational simulation.

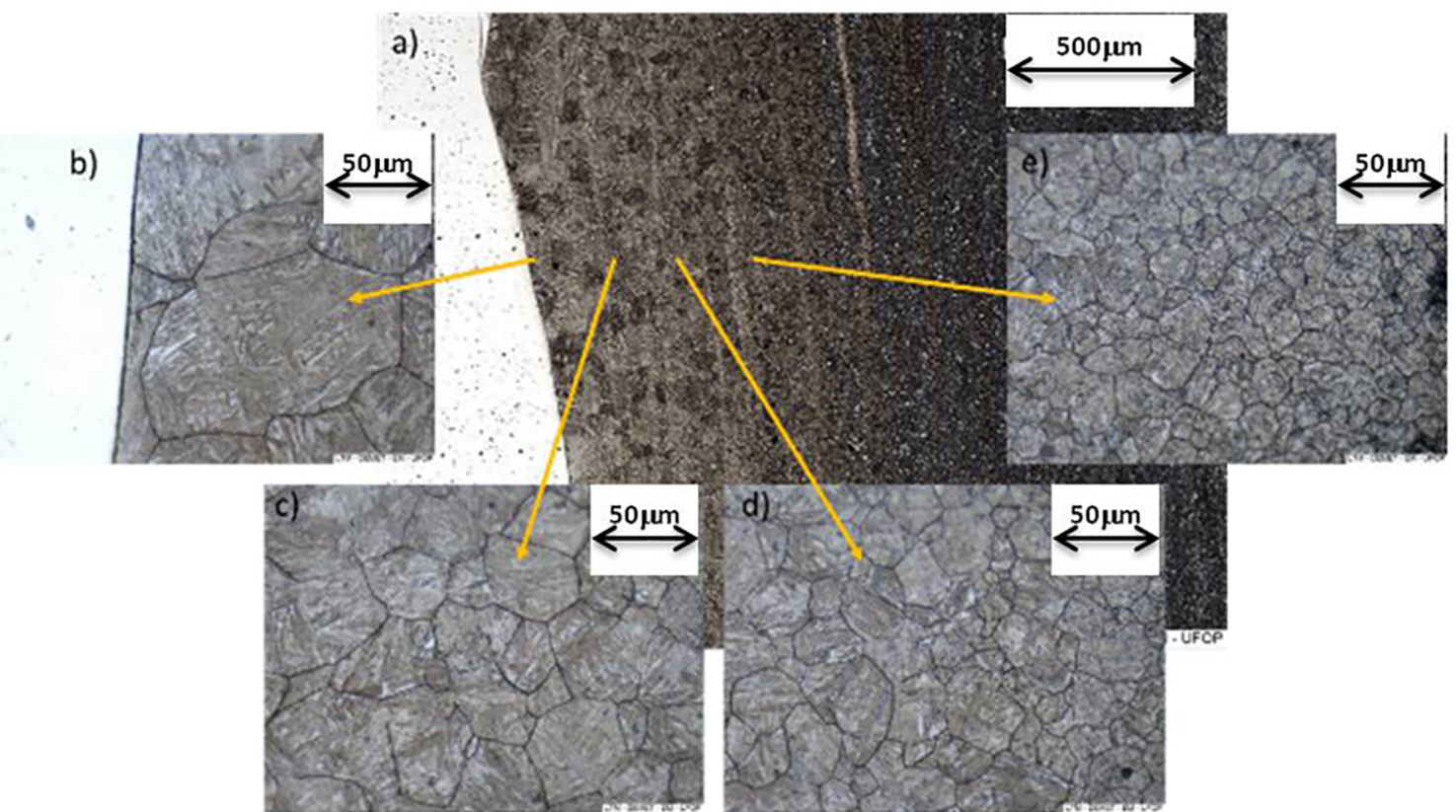

Figure 14. Micrographs of the steel substrate: a) showing the different sample areas. OM-50x. Nital $2 \%$. b) at superalloy-steel interface c) at $0.3 \mathrm{~mm}$ from the interface, d) at $0.5 \mathrm{~mm}$ from the interface, e) $0.7 \mathrm{~mm}$ from the interface - OM - 500x. Ether solution and Nital $4 \%$.

the lowest temperature where the complete austenitization occurs. Due to that, it was expected that this area presented the lowest austenitic grain size.

As revealed by the dilatometry and microhardness tests, the austenitic grain size significantly influences the phase transformations, the final microstructure and the mechanical behavior. Figure 14 presents OM analysis of the steel HAZ aiming to reveal the prior austenite grains. It can be seen that at the superalloy-steel interface, the austenitic grain size was coarser (Figure 14B) than those away from the superalloy-steel interface (Figure 14E).

\subsection{Post-cladding heat treatment}

As the main cause of the hardness increase at steel HAZ was well understood, a post-cladding heat treatment was proposed aiming to homogenize the hardness profile at superalloy-steel interface. Samples of both cladded superalloys were submitted to a heating at $1050^{\circ} \mathrm{C}$ for $1 \mathrm{~h}$ and then quenched in water at room temperature. In the sequence, samples were tempered for $1 \mathrm{~h}$ at $650^{\circ} \mathrm{C}$.

Figure 15 presents the obtained hardness profiles for both samples. It was observed that the proposed heat treatment was efficient aiming to homogenize the hardness profiles. The Inconel 625 hardness did not change significantly in comparison with their original hardness because, at the selected temperatures, the heat treatment times did not promote structural changes. However, for Hastelloy C276, it was observed a hardness increase of almost $100 \mathrm{HV}$. According to technical literature, during the heating at $1050^{\circ} \mathrm{C}$ for one hour followed by water quenching, the precipitation of some 

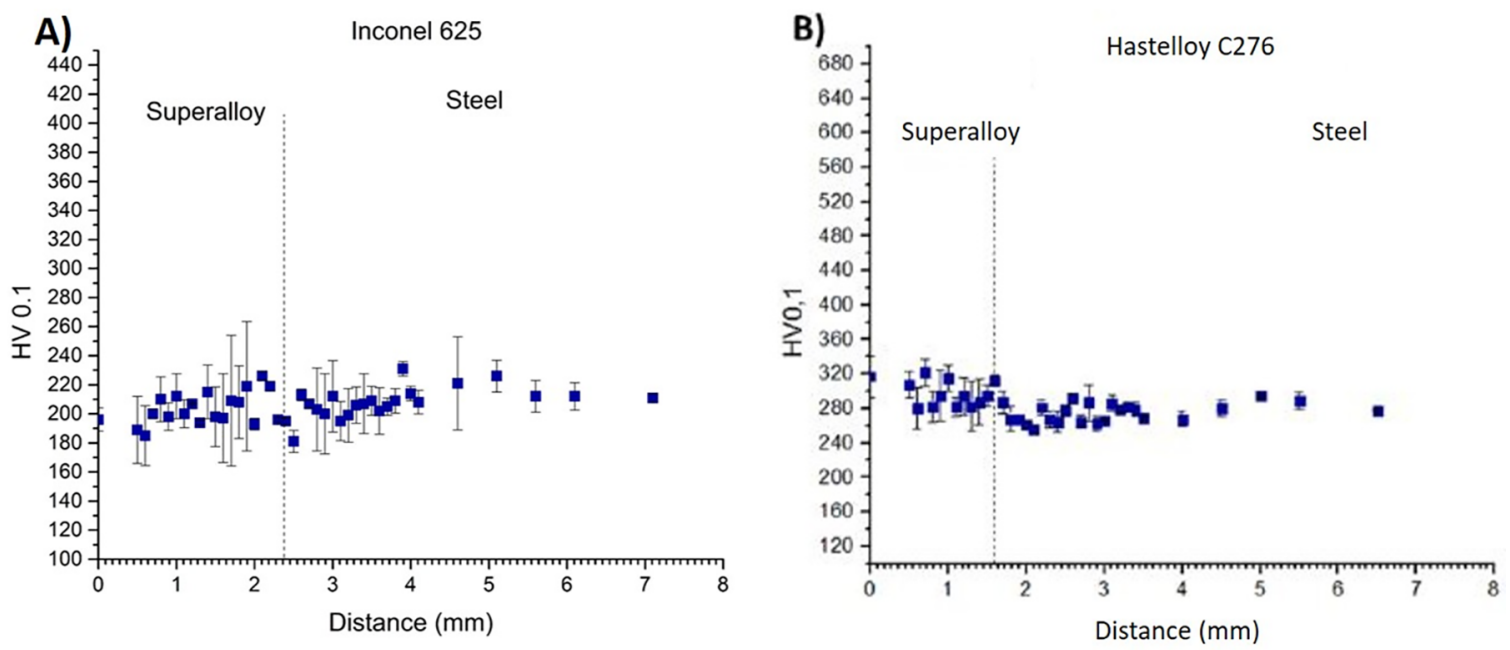

Figure 15. Microhardness profiles of nickel superalloys-steel interfaces after post-cladding.

carbides $\mathrm{M}_{23} \mathrm{C}_{6}$ and $\mathrm{MC}$ occurs, increasing its hardness. At $650^{\circ} \mathrm{C}$, the kinetics for the precipitation of secondary phases is very slow, and this second stage did not significant affect alloy hardness ${ }^{7-12}$. At steel substrate, the quench and tempering heat treatment promoted a homogenous tempered martensite, following an homogenous hardness profile.

\section{Conclusions}

The steel Ac1 and Ac3 temperatures were $739 \pm$ $11^{\circ} \mathrm{C}$ and $852 \pm 5^{\circ} \mathrm{C}$, respectively. The microstructural characterization of the samples subjected to the dilatometric tests was consistent with the obtained CCT diagrams for the austenitizing temperatures. The higher the austenitizing temperature, the more shifted to the right and down were the start and final transformation lines.

After the laser deposition of the both studied nickel superalloys, a significant variation of the steel hardness was observed next to the superalloy-steel interface. This region, known as HAZ, presented a hardness peak at approximately $0.7 \mathrm{~mm}$ from the interface, reaching $350 \mathrm{HV}$. In regions displaced right from the peak, the hardness falls again, reaching minimum value around $160 \mathrm{HV}$.

The hardness profile at the HAZ region was justified by the microstructural gradient verified in this area due to the different heating cycles that each region of the substrate was subjected during the laser deposition process. The hardness peak was related to the lowest austenitic grain size obtained during the cladding procedure and a fine martensite resultant from the fast cooling.

The temperature profiles obtained by computational simulation, using the Rosenthal model, were satisfactorily close to the experimental results. It is verified, through the cooling rates obtained in the simulation, and micrographs of prior austenic grains, that the areas that were completely austenitized transformed themselves into martensite with different morphologies during steel cooling.

The proposed heat treatment was efficient aiming to homogenize the hardness profile at superalloy-steel interface. The proposed heat treatment conditions are easily applied in industrial facilities, because similar heat treatments are already applied in some types of API products and the required infrastructure already exists.

\section{Acknowledgements}

The authors would like to acknowledge the Coordenação de Aperfeiçoamento de Pessoal de Nível Superior (CAPES) and Conselho Nacional de Desenvolvimento Científico e Tecnológico (CNPq) for the financial support.

\section{References}

1. Santos MC, Pinheiro CL, Cardoso Filho JCA. Investigation of the corrosive process caused by pulp bauxite in pipeline carbon steel. Matéria (Rio J). 2015;20(1):178-184.

2. Santana RAC, Prasad S, Santana FSM. Electrolytic coating with corrosion and wear resistant Ni-W-B amorphous alloy. Eclética Química. 2003;28(1):69-76.

3. Nóbrega ACV, Barbosa AFF, Silva DR, Pimenta GS, Peixoto DG. Estudo de caso - Corrosão interna em dutos transportadores de gás natural. In: $2^{\circ}$ Congresso Brasileiro de $\mathrm{P} \& \mathrm{D}$ em Petróleo e Gás; 2003 Jun 15-18; Rio de Janeiro, RJ, Brazil.

4. Al-Fadhli HY, Stokes J, Hashmi MSJ, Yilbas BS. The erosioncorrosion behavior of high velocity oxy-fuel (HVOF) thermally sprayed inconel-625 coatings on different metallic surfaces. Surface and Coatings Technology. 2006;200(20-21):5782-5788.

5. Morsi MS, El Gwad SAA, Shoeib MA, Ahmed KF. Effect of Air Plasma Sprays Parameters on Coating Performance in Zirconia-Based Thermal Barrier Coatings. International Journal Electrochemical Science. 2012;7:2811-2831. 
6. Barletta M, Bolelli G, Bonferroni B, Lusvarghi L. Wear and Corrosion Behavior of HVOF-Sprayed WC-CoCr Coatings on Alloys. Journal of Thermal Spray Technology. 2010;19(12):358-367.

7. Silva CC, de Miranda EC, Motta MF, de Miranda HC, Farias JP. Minimization of defects in nickel-based superalloy weld overlay deposited by the GTAW cold wire feed process. Soldagem \& Inspeção. 2014;19(4):323-332.

8. Xing X, Di X, Wang B. The effect of post-weld heat treatment temperature on the microstructure of Inconel 625 deposited metal. Journal of Alloys and Compounds. 2014;593:110-116.

9. Xu F, Lv Y, Liu Y, Shu F, He P, Xu B. Microstructural Evolution and Mechanical Properties of Inconel 625 Alloy during Pulsed Plasma Arc Deposition Process. Journal of Materials Science \& Technology. 2013;29(5):480-488.

10. Shakil M, Ahmad M, Tariq NH, Hasan BA, Akhter JI, Ahmed E, et al. Microstructure and hardness studies of electron beam welded Inconel 625 and stainless steel 304L. Vacuum. 2014;110:121-126.

11. Ma G, Wu D, Niu F, Zou H. Microstructure evolution and mechanical property of pulsed laser welded Ni-based superalloy. Optics and Lasers in Engineering. 2015;72:39-46.

12. Li S, Wei Q, Shi Y, Zhu Z, Zhang D. Microstructure Characteristics of Inconel 625 Superalloy Manufactured by Selective Laser Melting. Journal of Materials Science \& Technology. 2015;31(9):946-952.

13. Ferreira LS. Microestrutura e propriedades de revestimentos de liga Hastelloy $\mathrm{C} 276$ ( NiCrMoW) obtidos por plasma com arco transferido sobre aços API 5 L e AISI 316. [Dissertation]. Curitiba: Federal University of Paraná; 2014.

14. dos Santos MWB. Aspectos metalúrgicos de revestimentos em dutos depositados com a superliga de níquel ERNiCrMo-4 pelos processos MIG convencional e MIG com adição de arame frio. [Dissertation]. Belém: Federal University of Pará; 2012.

15. Miura R, Sakuraba M. Clad Steel Pipe for Corrosive Gas Transportation. In: Offshore Technology Conference; 1995 May 1-4; Houston, TX, USA.

16. Aihua BW, Zengyi T, Beidi Z. Laser Beam Cladding of Seating Surfaces on Exhaust Valves. Welding Research Supplement. 1991;4:106S-109S.

17. Otegui JL, Kerr HW, Burns DJ, Mohaupt UH. Fatigue crack initiation from defects at weld toes in steel. International Journal of Pressure Vessels and Piping. 1989;38(5):385-417.

18. Sharma SK, Maheshwari S. A review on welding of high strength oil and gas pipeline steels. Journal of Natural Gas Science and Engineering. 2017;38:203-217.
19. Ottersböck MJ, Leitner M, Stoschka M, Maurer W. Effect of Weld Defects on the Fatigue Strength of Ultra High Strength Steels. Procedia Engineering. 2016;160:214-222.

20. Marulo G, Baumgartner J, Frendo F. Fatigue strength assessment of laser welded thin-walled joints made of mild and high strength steel. International Journal of Fatigue. 2017;96:142-151.

21. de Andrés GC, Caballero FG, Capdevila C, Álvarez LF. Application of dilatometric analysis to the study of solid-solid phase transformations in steels. Materials Characterization. 2002;48(1):101-111.

22. Pawlowski B, Bala P, Dziurka R. Improper Interpretation of Dilatometric Data for Cooling Transformation in Steels. Archives of Metallurgy and Materials. 2014;59(3):1159-1161.

23. Messler RW Jr. Principles of Welding: Process, Phisics, Chemistry, and Metallurgy. Weinhein: Wiley VCH; 2004.

24. De Lima MSF. Phase Transformations during Laser Processing of Aerospace Metallic Materials. Advanced Materials Research. 2016;1135:179-201.

25. American Petroleum Institute. API 5CT: Specification for Casing and Tubing. $9^{\text {th }}$ ed. Washington: American Petroleum Institute; 2011.

26. Li X, Ma X, Subramanian SV, Shang C, Misra RDK. Influence of prior austenite grain size on martensite-austenite constituent and toughness in the heat affected zone of $700 \mathrm{Mpa}$ high strength linepipe steel. Materials Science and Engineering: A. 2014;616:141-147.

27. Prawoto Y, Jasmawati N, Sumeru K. Effect of Prior Austenite Grain Size on the Morphology and Mechanical Properties of Martensite in Medium Carbon Steel. Journal of Materials Science \& Technology. 2012;28(5):461-466.

28. Martins PGM, Faria GL, Godefroid LB, Costa RT. Utilização de um ataque por imersão na caracterização da influência da temperatura e do tempo de austenitização sobre o tamanho de grão austenítico e morfologia da martensita em um aço do tipo ABNT1045. In: 69th ABM Annual Congress; 2014 Jul 21-24; São Paulo, SP, Brazil.

29. Lay GY, Wood WE, Clark RA, Zackay VF, Parker ER. The effect of austenitizing temperature on the microstructure and mechanical properties of as-quenched 4340 steel. Metallurgical Transactions. 1974;5(7):1663-1670.

30. Rickman JM, Tong WS, Barmak K. Impact of heterogeneous boundary nucleation on transformation kinetics and microstructure. Acta Materialia. 1997;45(3):1153-1166. 